\title{
Soil acidification of alfisols influenced by nitrate and ammonium nitrogen level in tea plantation
}

\author{
Hui Wang ${ }^{1 *}$, Hao Zhang ${ }^{1}$, Yan Zhao ${ }^{1}$, Renkou $\mathrm{Xu}^{2}$ \\ (1. Department of Environment Engineering, Henan University of Science and Technology, Luoyang 471023, China; \\ 2. State Key Laboratory of Soil and Sustainable Agriculture, Institute of Soil Science, Chinese Academy of Sciences, Nanjing 210008, China)
}

\begin{abstract}
Nitrogen is an important fertilizer in tea production, but it is also an important factor in tea garden soil acidification. The relationship between absorption and transport of different forms of nitrogen in the tea plant and soil acidification is still unknown. In order to explore the different characteristics of absorption, utilization and distribution of nitrogen, stable isotope ${ }^{15} \mathrm{~N}$ tracer technique was used to measure the absorption, utilization and allocation of nitrate nitrogen $\left(\mathrm{NO}_{3^{-}}{ }^{15} \mathrm{~N}\right)$ and ammonium nitrogen $\left(\mathrm{NH}_{4}{ }^{-15} \mathrm{~N}\right)$ under the same nitrogen application amount of tea tree seedlings as experimental materials. The results showed that the tea seedlings had the same pattern of nitrogen application: tissue nitrogen content increased after fertilization, remarkable rising at $7 \mathrm{~d}$ and the absorption speed increased quickly after $28 \mathrm{~d}$, finally reached its maximum at $56 \mathrm{~d}$. The nitrogen use efficiency of two nitrogen sources in two kinds of soil varied not significantly. The maximum $\mathrm{NUE}_{\text {of }} \mathrm{NO}_{3}{ }^{-15} \mathrm{~N}^{15}$ reached $12.66 \%$, and at the same time $\mathrm{NH}_{4}{ }^{-15} \mathrm{~N}$ utilization rose up to $11.54 \%$. According to the absorption of soil nitrogen and nitrogen fertilizer in the two kinds of soil, it is concluded that the soil nitrogen cannot meet the growth needs of tea tree and extra nitrogen supply was required. The declined soil $\mathrm{pH}$ indicated that fertilizer should be used in moderation, which can not only satisfy the growth of tea tree but also to restrict soil acidification.
\end{abstract}

Keywords: tea tree, ${ }^{15} \mathrm{~N}$, nitrate nitrogen, ammonium nitrogen, soil acidification

DOI: $10.25165 /$ j.ijabe.20181104.2078

Citation: Wang H, Zhang H, Zhao Y, Xu R K. Soil acidification of alfisols influenced by nitrate and ammonium nitrogen level in tea plantation. Int J Agric \& Biol Eng, 2018; 11(4): 168-172.

\section{Introduction}

Tea (Camellia sinensis) is a major commercial crop in many countries in tropical and subtropical regions, including China, India and Sri Lanka. There are about 2.72 million $\mathrm{hm}^{2}$ of land used for tea cultivation globally, with 1.02 million $\mathrm{hm}^{2}$ in China alone ${ }^{[1]}$. Tea is an unusual crop because the soil after tea planting becomes strongly acidified, and soil $\mathrm{pH}$ generally continues to decrease with the increase of stand age $\mathrm{e}^{[2,3]}$. The problems of tea garden soil acidification are intensively researched in early 1970-1980s, and many tea producing countries presented the tea garden soil acidification in various degrees. It is reported that $38.64 \%$ of Japanese tea gardens had an average soil $\mathrm{pH}$ under 3.9, 37.52\% of them had an average soil $\mathrm{pH}$ from 4.0 to 4.9 , and the tea gardens with optimal soil $\mathrm{pH}$ for tea tree growth only accounts $15.11 \%^{[4]}$. The $\mathrm{pH}$ of tea garden soil in Assam area in South Indian dropped down significantly ${ }^{[5,6]}$.

Fertilization is regarded as an important factor in affecting the tea garden soil acidification. More nitrogen fertilizer and less organic fertilizer can lead to more serious tea garden soil acidification in current China. The tea tree is leaf using crop, it is special fond of nitrogen. Tea plantation generally uses ammonium nitrogen as nitrogen fertilizer. After absorbing

\section{Received date: 2017-02-21 Accepted date: 2017-11-0}

Biographies: Hao Zhang, Master candidate, research interests: soil remediation, Email: 1352009076@qq.com; Yan Zhao, PhD, research interests: soil remediation, Email: zhaoyanvip2008@163.com; Renkou Xu, PhD, Professor, research interests: soil remediation, Email: rkxu@issas.ac.cn.

*Corresponding author: Hui Wang, $\mathrm{PhD}$, Associate Professor, research interests: soil remediation. Department of Environment Engineering, Henan University of Science \& Technology, Luoyang 471023, China. Tel: +86-15037938700, Fax: +86-379-64231914, Email: wanghui_peony@163.com. ammonium nitrogen, tea tree root release a great amount of $\mathrm{H}^{+}$, which produced a sustained drop in the soil $\mathrm{pH}$. With the increase application of chemical nitrogen fertilizer and the extension of application time, soil acidification was obviously deepened. In addition to tea tree's metabolism in tea garden, tea garden soil acidification affected by human cultivation process is even more serious. Fertilization is a prime reason which has direct impact on tea garden soil acidification ${ }^{[7-9]}$. It is reported that China main agricultural soil acidification was significant since 1980s. The survey found that excessive nitrogen fertilization is the main cause of the farmland soil acidification. For tea tree planting, the removal of tea products is the main cause of soil acidification ${ }^{[10]}$. When nitrogen fertilizer was applied, the yield and biomass of tea tree above ground were increased. The crop harvest led to more alkali removed from soil and further accelerate soil acidification process $^{[11]}$. Another major reason of nitrogen fertilizer accelerating soil acidification is that the nitrification of ammonium nitrogen in soil and the following $\mathrm{NO}_{3}{ }^{-}$leaching ${ }^{[4]}$. However, the effect of soil nitrogen cycle, the contribution of soil nitrification and soil mineralization on soil acidification is rarely reported.

In order to explore the transferring regularity of different forms of nitrogen in tea tree, the stable isotope ${ }^{15} \mathrm{~N}$ tracer technique was used to measure the absorption, utilization and allocation of nitrate nitrogen $\left(\mathrm{NO}_{3}{ }^{-15} \mathrm{~N}\right)$ and ammonium nitrogen $\left(\mathrm{NH}_{4}{ }^{-{ }^{-}}{ }^{15} \mathrm{~N}\right)$ under the same nitrogen application rate. Furthermore, this study also demonstrate the effects of soil acidification on soil aluminum chemistry and soil exchangeable base cations, provides theory basis for soil acidification controlling.

\section{Materials and methods}

\subsection{Plant materials}

The experimental tea seedlings were collected from Wuxi 
institute of tea science of one-year cutting seedlings. The new tea seedlings' root, stem and leaf were washed by tap water, and the roots were washed three times with deionized water. The uniformly tea seedlings were selected and every three seedlings were collected into one $1 \mathrm{~L}$ plastic bucket with $25 \%$ nutrient solution, roots were kept away from light. Nutrient solution composition was as follows: $\left(\mathrm{NH}_{4}\right)_{2} \mathrm{SO}_{4}, 750 \mu \mathrm{mol} / \mathrm{L}$; $\mathrm{Ca}\left(\mathrm{NO}_{3}\right)_{2} \cdot 4 \mathrm{H}_{2} \mathrm{O}, 250 \mu \mathrm{mol} / \mathrm{L} ; \mathrm{KH}_{2} \mathrm{PO}_{4}, 30 \mu \mathrm{mol} / \mathrm{L} ; \mathrm{K}_{2} \mathrm{SO}_{4}$, $300 \mu \mathrm{mol} / \mathrm{L} ; \mathrm{CaCl}_{2}, 20 \mu \mathrm{mol} / \mathrm{L} ; \mathrm{MgSO}_{4}, 210 \mu \mathrm{mol} / \mathrm{L} ; \mathrm{ZnSO}_{4} \cdot 7 \mathrm{H}_{2} \mathrm{O}$, $0.51 \mu \mathrm{mol} / \mathrm{L} ; \mathrm{CuSO}_{4} \cdot 5 \mathrm{H}_{2} \mathrm{O}, 0.13 \mu \mathrm{mol} / \mathrm{L} ; \mathrm{MnSO}_{4} \cdot \mathrm{H}_{2} \mathrm{O}, 0.5 \mu \mathrm{mol} / \mathrm{L}$; $\mathrm{H}_{3} \mathrm{BO}_{3}, 3.33 \mu \mathrm{mol} / \mathrm{L}$; Fe Na EDTA, $2.1 \mu \mathrm{mol} / \mathrm{L} ; \mathrm{Na}_{2} \mathrm{MoO}_{4} \cdot 2 \mathrm{H}_{2} \mathrm{O}$, $0.17 \mu \mathrm{mol} / \mathrm{L}$. When large amount of new small white roots grow out, tea seedlings were transferred into greenhouse with $3 \mathrm{~h}$ ventilation every morning and afternoon. After $7 \mathrm{~d}$ cultivation, the robust tea seedlings under consistent growth condition were chosen for test in September 2014. The pot experiments were conducted in light incubator. The dry weight of each testing basin soil is $0.9 \mathrm{~kg}$.

\subsection{Soil sampling and treatment}

Four kinds of soil (quaternary red clay, granite and limestone soil parent material development, including yellow brown soil, yellow soil, brown soil and red soil) were choose from north temperate zone and subtropical zone. These soils were not tea planting soil and not polluted wasteland soil. The experimental yellow brown soil was collected from Nanjing, Jiangsu province, the depth of sampling is 0 to $10 \mathrm{~cm}$, soil organic matter content is $30.72 \mathrm{~g} / \mathrm{kg}$, cation exchange capacity (CEC) is $14.77 \mathrm{cmol}_{(+)} / \mathrm{kg}$, soil $\mathrm{pH}$ is 5.86. The experimental yellow soil was collected from Chongqing, depth of sampling is 0 to $10 \mathrm{~cm}$, soil organic matter content is $25.74 \mathrm{~g} / \mathrm{kg}, \mathrm{CEC}$ is $8.72 \mathrm{cmol}_{(+)} / \mathrm{kg}$, soil $\mathrm{pH}$ is 4.52 . The experimental brown soil was collected from Xinyang, Henan province, depth of sampling is 0 to $10 \mathrm{~cm}$, soil organic matter content is $31.65 \mathrm{~g} / \mathrm{kg}, \mathrm{CEC}$ is $15.84 \mathrm{cmol}_{(+)} / \mathrm{kg}$, soil $\mathrm{pH}$ is 6.71 . The experimental red soil was collected from Guilin in Guangxi province, depth of sampling is 0 to $10 \mathrm{~cm}$, soil organic matter content is $28.59 \mathrm{~g} / \mathrm{kg}, \mathrm{CEC}$ is $9.08 \mathrm{cmol}_{(+)} / \mathrm{kg}$, soil $\mathrm{pH}$ is 5.54 . These four kinds of soil samples were natural air dried and crushed to pass $2 \mathrm{~mm}$ sieve in cylindrical test POTS $(20 \mathrm{~cm}$ in diameter, $15 \mathrm{~cm}$ high). $8 \mathrm{~kg}$ of each kind of soil was added into a barrel, added $2.35 \mathrm{~g} \mathrm{P}_{2} \mathrm{O}_{5}, 2.89 \mathrm{~g} \mathrm{~K}_{2} \mathrm{O}$, and blended to mix together. Soil total nitrogen content is $1.0 \mathrm{~g} / \mathrm{kg}$.

${ }^{15} \mathrm{~N}$-single marking ammonium nitrate fertilizer with concentration of $10.19 \%$ was provided by Shanghai Chemical Industry Research Institute. Treatment 1 applied $0.57142 \mathrm{~g}$ $\mathrm{NO}_{3}{ }^{15} \mathrm{~N}$ marked $\mathrm{NH}_{4} \mathrm{NO}_{3}$ in each basin, tagged as $\mathrm{NO}_{3}{ }^{-{ }^{15}} \mathrm{~N} \mathrm{~N}$ fertilizer, and applied $0.2 \mathrm{~g}$ nitrification inhibitor dicyandiamide at the same time. Treatment 2 applied $0.57142 \mathrm{~g} \mathrm{NH}_{4^{-}}{ }^{15} \mathrm{~N}$ marked $\mathrm{NH}_{4} \mathrm{NO}_{3}$ in each basin, tagged as $\mathrm{NH}_{4^{-}}{ }^{15} \mathrm{~N}$ fertilizer. Four replicates were set in each treatment, with a total of 128 pots seedling.

\subsection{Soil and plant analysis}

After fertilization, plant and soil samples were collected every $7 \mathrm{~d}, 14 \mathrm{~d}, 28 \mathrm{~d}$ and $56 \mathrm{~d}$. 2 plant strains were selected into samples each treatment every time, the total is 8 plant strains for each treatment. Samples were separated into root, stem and leaf, washed with tap water and distilled water three times, oven-dried under $105^{\circ} \mathrm{C}-110^{\circ} \mathrm{C}$ for $30 \mathrm{~min}$, then dried in $65^{\circ} \mathrm{C}$ with $48 \mathrm{~h}$. The plant samples were grinded to pass $0.125 \mathrm{~mm}$ sieve and the dry weight of root, stem and leaf was weighted. Soil samples were also air-dried and ground to pass $2 \mathrm{~mm}$ sieve, and stored in plastic $\operatorname{bags}^{[12,13]}$

Total nitrogen content is analyzed by carbon and nitrogen analyzer. ${ }^{15} \mathrm{~N}$ abundance of each plant part was determined by MAT-251 mass spectrometer in Institute of Atomic Energy, Chinese Academy of Agricultural Sciences.

The soil $\mathrm{pH}$ was determined using a combination glass electrode in 1:2.5 (w/v) ratio of soil-deionized water mixture ${ }^{[14]}$. Exchangeable $\mathrm{Ca}, \mathrm{Mg}, \mathrm{K}$, and $\mathrm{Na}$ were extracted by $1.0 \mathrm{~mol} / \mathrm{L}$ $\mathrm{NH}_{4} \mathrm{Ac}$ at $\mathrm{pH} 7.0$, and the cations were measured using atomic adsorption spectrometry ${ }^{[15]}$. The CEC was determined by the Kjeldahl Nitrogen Determination method ${ }^{[16]}$.

Exchangeable acidity and exchangeable $\mathrm{Al}$ of soils were extracted with $1.0 \mathrm{~mol} / \mathrm{L} \mathrm{KCl}$ followed by titrating with standard $\mathrm{NaOH}$ solution ${ }^{[17]}$.

\subsection{Data analysis} al. $^{[12,13]}$

The NUE was calculated according to the method of Dong et

SPSS 15.0 (SPSS Inc., Chicago, IL, USA) was used for data processing and statistical analysis.

\section{Results and discussion}

\subsection{Soil pH}

The $\mathrm{pH}$ of the soil samples in different treatments are shown in Table 1. The incubation of tea seedlings caused decreases of $\mathrm{pH}$ in all types of soil with most of the $\mathrm{pH}$ decreases occurred within $56 \mathrm{~d}$. The four types of soil have different $\mathrm{pH}$ values. With the increase of cultivation time, soils $\mathrm{pH}$ value of four treatment samples were both declined. In $56 \mathrm{~d}$, soil $\mathrm{pH}$ of brown soil under $\mathrm{NO}_{3}{ }^{15} \mathrm{~N}$ treatment dropped from 6.71 to 6.48 , soil $\mathrm{pH}$ of brown soil under $\mathrm{NH}_{4}{ }^{-15} \mathrm{~N}$ treatment dropped from 6.62 to 6.38 ; soil $\mathrm{pH}$ of red soil under $\mathrm{NO}_{3}{ }^{-}{ }^{15} \mathrm{~N}$ treatment dropped from 5.54 to 5.29 , and soil $\mathrm{pH}$ of red soil under $\mathrm{NH}_{4^{-}}{ }^{15} \mathrm{~N}$ treatment dropped from 5.42 to 5.18. Yellow soil and yellow brown soil follows the same pattern, while $\mathrm{pH}$ of yellow soil is significantly higher than yellow brown soil. It is also noticed that in all kinds of soil, $\mathrm{NH}_{4}{ }^{-}{ }^{15} \mathrm{~N}$ treatment leads to lower soil $\mathrm{pH}$ than $\mathrm{NO}_{3}-{ }^{15} \mathrm{~N}$ treatment.

Table 1 Different tea root soil $\mathrm{pH}$ value

\begin{tabular}{|c|c|c|c|c|c|c|}
\hline Soil & Treatment & 0 & $7 \mathrm{~d}$ & $14 \mathrm{~d}$ & $28 \mathrm{~d}$ & $56 \mathrm{~d}$ \\
\hline \multirow{2}{*}{ Brown soil } & $\mathrm{NO}_{3}{ }^{15} \mathrm{~N}$ & $6.71 \pm 0.15$ & $6.65 \pm 0.24$ & $6.59 \pm 0.24$ & $6.56 \pm 0.18$ & $6.48 \pm 0.37$ \\
\hline & $\mathrm{NH}_{4^{-}}{ }^{15} \mathrm{~N}$ & $6.62 \pm 0.28$ & $6.57 \pm 0.21$ & $6.52 \pm 0.15$ & $6.43 \pm 0.23$ & $6.38 \pm 0.32$ \\
\hline \multirow{2}{*}{ Red soil } & $\mathrm{NO}_{3}{ }^{15} \mathrm{~N}$ & $5.54 \pm 0.13$ & $5.48 \pm 0.19$ & $5.43 \pm 0.24$ & $5.36 \pm 0.12$ & $5.29 \pm 0.25$ \\
\hline & $\mathrm{NH}_{4^{-}}{ }^{15} \mathrm{~N}$ & $5.42 \pm 0.16$ & $5.39 \pm 0.21$ & $5.32 \pm 0.16$ & $5.25 \pm 0.25$ & $5.18 \pm 0.15$ \\
\hline \multirow{2}{*}{ Yellow brown soil } & $\mathrm{NO}_{3}{ }^{15} \mathrm{~N}$ & $5.21 \pm 0.15$ & $5.16 \pm 0.25$ & $5.07 \pm 0.24$ & $4.95 \pm 0.18$ & $4.89 \pm 0.30$ \\
\hline & $\mathrm{NH}_{4^{-}}{ }^{15} \mathrm{~N}$ & $5.22 \pm 0.28$ & $5.2 \pm 0.21$ & $5.15 \pm 0.15$ & $4.93 \pm 0.23$ & $4.85 \pm 0.32$ \\
\hline \multirow{2}{*}{ Yellow soil } & $\mathrm{NO}_{3}{ }^{15} \mathrm{~N}$ & $6.62 \pm 0.16$ & $6.59 \pm 0.24$ & $6.54 \pm 0.19$ & $5.95 \pm 0.25$ & $5.48 \pm 0.15$ \\
\hline & $\mathrm{NH}_{4^{-}}{ }^{15} \mathrm{~N}$ & $6.65 \pm 0.13$ & $6.6 \pm 0.19$ & $6.43 \pm 0.24$ & $5.83 \pm 0.18$ & $5.45 \pm 0.25$ \\
\hline
\end{tabular}


It is reported that tea tree absorbed ammonium nitrogen greatly higher than nitrate nitrogen. After absorption of ammonium nitrogen, tea tree roots released $\mathrm{H}^{+}$to decreased soil $\mathrm{pH}^{[18-20]}$. Compare to ammonium nitrogen, the adsorption of nitrate nitrogen releases more $\mathrm{OH}^{-}$and relatively increase soil $\mathrm{pH}$. However, this experiment applied same amount of ammonium nitrate and nitrate nitrogen with only differences on ${ }^{15} \mathrm{~N}$ labeling, so soil $\mathrm{pH}$ change trend of the different treatments in same soil roughly belonged to normal phenomenon.

Since the initial cultivate soil nitrogen mineralization absorb protons and urea hydrolysis, which increases in line with Table 1, the beginning of the cultivation of soil ammonium nitrogen content; As the nitrification, 1 mol $\mathrm{NH}_{4^{-}}{ }^{15} \mathrm{~N}$ oxidized to $\mathrm{NO}_{3}{ }^{-15} \mathrm{~N}$, then $2 \mathrm{~mol} \mathrm{H}^{+}$release into the soil, so the soil $\mathrm{pH}$ decreases. Soil $\mathrm{pH}$ changes only four different amplitudes, the number of produced mainly with soil buffering capacity, urea hydrolysis degree and nitrogen transformation process related to proton ${ }^{[21-24]}$.

\subsection{Nitrogen absorption of tea tree and soil}

\subsubsection{Nitrogen absorption in brown soil and yellow soil}

As shown in Figure 1, the different processing of tea tree nitrogen absorption markers presented a certain dynamic change. $7 \mathrm{~d}$ after fertilization, tea tree absorbed low nitrogen, $\mathrm{NO}_{3}{ }^{-15} \mathrm{~N}$ nitrogen treatment absorption of brown soil of tea tree is $0.0047 \mathrm{~g} / \mathrm{kg}, \mathrm{NH}_{4^{-}}{ }^{15} \mathrm{~N}$ absorption treatment of brown soil of tea tree nitrogen is $0.0051 \mathrm{~g} / \mathrm{kg}$; Yellow soil uptake in $7 \mathrm{~d}$ is $0.0004 \mathrm{~g} / \mathrm{kg}$, but the uptake of $28 \mathrm{~d}$ is $0.0103 \mathrm{~g} / \mathrm{kg}$.

After $28 \mathrm{~d}$, nitrogen absorption of tea tree was getting slowed, at $56 \mathrm{~d}$ is in the max, $\mathrm{NO}_{3^{-}}{ }^{15} \mathrm{~N}$ treatment of brown soil of tea tree reached the maximum, the absorption amount is $0.0163 \mathrm{~g} / \mathrm{kg}$, $\mathrm{NH}_{4^{-}}{ }^{15} \mathrm{~N}$ treatment of brown soil reached maximum , the amount is $0.0176 \mathrm{~g} / \mathrm{kg}$, and nitrogen uptake in yellow soil is $0.0134 \mathrm{~g} / \mathrm{kg}$. In generally, for two kinds of soils, tag nitrogen absorption of $\mathrm{NH}_{4}{ }^{-}{ }^{15} \mathrm{~N}$ treatment in tea tree is higher than $\mathrm{NO}_{3}{ }^{-}{ }^{15} \mathrm{~N}$ treatment of tea tree.

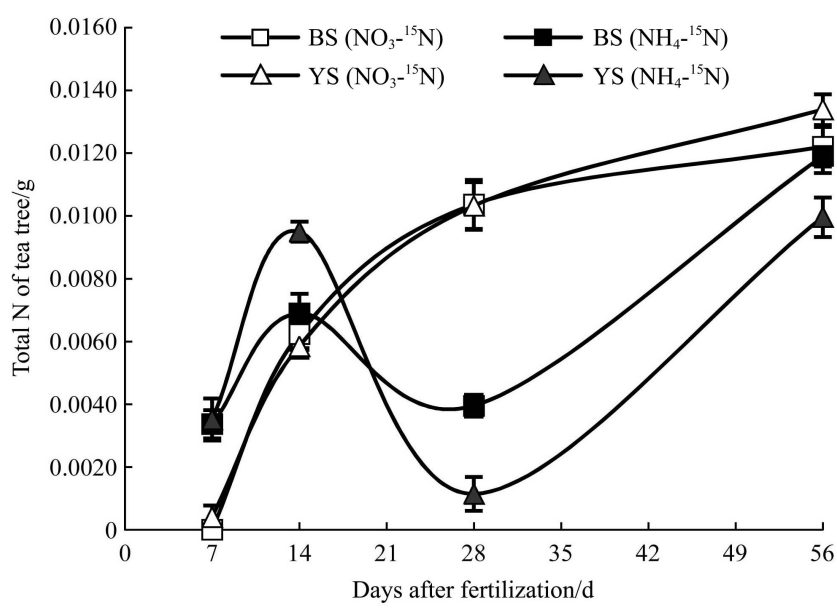

Figure 1 Nitrogen fertilizer uptake in different treatment and different types of soil (brown soil and yellow soil)

\subsubsection{Nitrogen absorption in yellow brown soil and red soil}

The nitrogen fertilizer absorption in yellow brown soil and red soil can be seen from the Figure 2. The absorption of different nitrogen species of tea tree presented certain regularity.

Nitrogen absorption was kept at a high ratio in the first $14 \mathrm{~d}$ after fertilization, the absorption amount in red soil $\mathrm{NH}_{4^{-}}{ }^{15} \mathrm{~N}$ treatment is $0.0055 \mathrm{~g} / \mathrm{kg}$, and the absorption amount in red soil $\mathrm{NO}_{3}{ }^{15} \mathrm{~N}$ treatment $\mathrm{t}$ is $0.0049 \mathrm{~g} / \mathrm{kg}$. From $14 \mathrm{~d}$ to $28 \mathrm{~d}$ after fertilization, nitrogen absorption in tea tree was slowly increased.
The soil applied ${ }^{15} \mathrm{~N}-\mathrm{NO}_{3}$ fertilizer, the absorption rate of 0 to $28 \mathrm{~d}$ is faster, yellow brown soil uptake is $0.0039 \mathrm{~g} / \mathrm{kg}$ in $7 \mathrm{~d}$, but the uptake in $28 \mathrm{~d}$ increased to $0.0104 \mathrm{~g} / \mathrm{kg}$. After $28 \mathrm{~d}$, the absorption rate declined, uptake of nitrogen in yellow brown soil in $56 \mathrm{~d}$ is $0.0122 \mathrm{~g} / \mathrm{kg} \mathrm{NO}_{3}{ }^{-15} \mathrm{~N}$ nitrogen uptake in red soil in $56 \mathrm{~d}$ is $0.0169 \mathrm{~g} / \mathrm{kg}$, while $\mathrm{NH}_{4^{-}}{ }^{15} \mathrm{~N}$ nitrogen uptake in read soil is $0.0182 \mathrm{~g} / \mathrm{kg}$. To exert $\mathrm{NH}_{4^{-}}{ }^{15} \mathrm{~N}$ for two kinds of soil nitrogen volatile, absorption rate in 0 to $7 \mathrm{~d}$ rose rapidly, but declined after $28 \mathrm{~d}$. After $56 \mathrm{~d}$ the absorption presented the same level of $\mathrm{NO}_{3^{-}}{ }^{15} \mathrm{~N}$. These results suggest that urea hydrolysis in yellow brown soil in tea garden is faster than in red soil in tea garden, while the absorption and utilization of $\mathrm{NH}_{4}{ }^{-}{ }^{15} \mathrm{~N}$ in these two soils takes longer time, which is conducive to tea for $\mathrm{NH}_{4}{ }^{15} \mathrm{~N}$ absorption and utilization. At the same time, two kinds of tea garden soil nitrification lag existed, in favor of tea to ammonium nitrogen ${ }^{[25-27]}$.

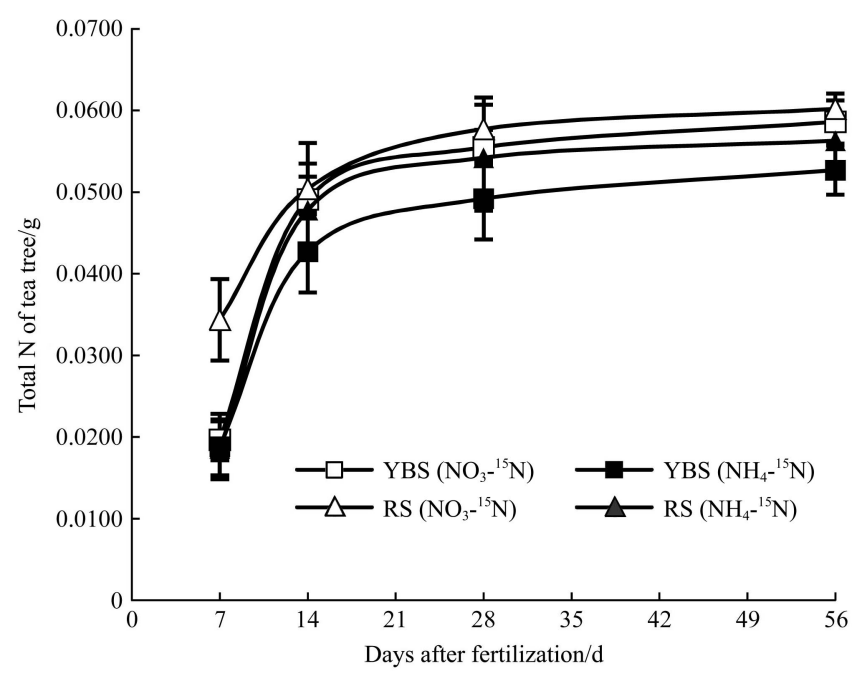

Figure 2 Nitrogen fertilizer uptake in different treatment and different types of soil (yellow brown soil and red soil)

\subsection{Soil nitrogen use efficiency}

Nitrogen use efficiency is the percentage of nitrogen absorption in plant utilization of the total nitrogen in soil. Nitrogen use efficiency is an important indicator to measure the rationality of nitrogen fertilizer. As seen from Table 2, a similar pattern of utilization rate of nitrogen fertilizer with nitrogen uptake was discovered. After the four kinds of soil are applied with $\mathrm{NO}_{3^{-}}{ }^{15} \mathrm{~N}$ fertilizer, utilization rate of 0 to $56 \mathrm{~d}$ is continuously increased, utilization rate in brown soil at $7 \mathrm{~d}$ was $4.40 \%$, and utilization rate at $28 \mathrm{~d}$ was $10.93 \%$, at the end of $56 \mathrm{~d}$ utilization rate reached $11.68 \%$. The utilization rate in red soil at $7 \mathrm{~d}$ was $4.83 \%$, utilization rate at $28 \mathrm{~d}$ was $8.54 \%$, at $56 \mathrm{~d}$ it reached $11.98 \%$. The utilization rate of $\mathrm{NH}_{4}{ }^{-15} \mathrm{~N}$ in four kinds of soil are also increased consistently, at $7 \mathrm{~d}$ utilization rate in brown soil was $5.37 \%$, at $28 \mathrm{~d}$ it was $12.38 \%$, and at last it reached $14.41 \%$ at $56 \mathrm{~d}$. The utilization rate in red soil also showed the same trend. Comparison showed that nitrogen fertilizer utilization rate is on the rise, but utilization rate of $\mathrm{NH}_{4^{-}}{ }^{15} \mathrm{~N}$ fertilizer was obviously higher than that of $\mathrm{NO}_{3}{ }^{-15} \mathrm{~N}$ fertilizer. The results show that the cultivation of tea can cause soil acidification, strongly acidic soils in tea plantation area can still occur even in the absence of additional nitrogen source. With the increase of cultivation $d$ the soil produced high concentrations of ammonia, create toxic circumstance for nitrification microorganisms to inhibit nitrification. In comparison, yellow soil has stronger nitrification than other soil, because $\mathrm{N}_{2} \mathrm{O}$ in yellow soil mainly came from 
aerobic nitrification process ${ }^{[28]}$. In addition, organic carbon, total nitrogen, inorganic nitrogen, porosity and other parameters in yellow soil were significantly higher than the red soil, which can provide sufficient substrate for the soil microbial activity and a higher rate of $\mathrm{N}_{2} \mathrm{O}$ emissions ${ }^{[29]}$. Increase amount of nitrogen leads to higher $\mathrm{N}_{2} \mathrm{O}$ emission, in which microbial growth may have primary effect than red soil property, but the exact reason need to be further studied ${ }^{[30]}$.

Table 2 Different soils of different forms of nitrogen utilization rate

\begin{tabular}{|c|c|c|c|c|c|}
\hline \multirow{2}{*}{ Soil } & \multirow{2}{*}{ Treatment } & \multicolumn{4}{|c|}{ Nitrogen fertilizer use efficiency $/ \%$} \\
\hline & & $7 \mathrm{~d}$ & $14 \mathrm{~d}$ & $28 \mathrm{~d}$ & $56 \mathrm{~d}$ \\
\hline \multirow{2}{*}{ Brown soil } & $\mathrm{NO}_{3}{ }^{15} \mathrm{~N}$ & $4.40 \pm 0.07$ & $8.20 \pm 0.45$ & $10.93 \pm 0.68$ & $11.68 \pm 0.02$ \\
\hline & $\mathrm{NH}_{4^{-}}{ }^{15} \mathrm{~N}$ & $5.37 \pm 0.09$ & $11.29 \pm 0.36$ & $12.38 \pm 0.19$ & $14.41 \pm 0.05$ \\
\hline \multirow{2}{*}{ Red soil } & $\mathrm{NO}_{3}{ }^{-15} \mathrm{~N}$ & $4.83 \pm 0.09$ & $6.51 \pm 0.24$ & $8.54 \pm 0.47$ & $11.98 \pm 0.21$ \\
\hline & $\mathrm{NH}_{4^{-}}{ }^{15} \mathrm{~N}$ & $7.56 \pm 0.05$ & $10.83 \pm 0.15$ & $11.52 \pm 0.28$ & $13.61 \pm 0.72$ \\
\hline \multirow{2}{*}{ Yellow brown soil } & $\mathrm{NO}_{3}{ }^{15} \mathrm{~N}$ & $3.66 \pm 0.05$ & $5.90 \pm 0.08$ & $9.80 \pm 0.10$ & $11.54 \pm 0.06$ \\
\hline & $\mathrm{NH}_{4-}{ }^{15} \mathrm{~N}$ & $3.18 \pm 0.09$ & $6.52 \pm 0.12$ & $3.74 \pm 0.04$ & $11.27 \pm 0.013$ \\
\hline \multirow{2}{*}{ Yellow soil } & $\mathrm{NO}_{3}{ }^{15} \mathrm{~N}$ & $0.38 \pm 0.07$ & $5.53 \pm 0.15$ & $9.76 \pm 0.11$ & $12.66 \pm 0.18$ \\
\hline & $\mathrm{NH}_{4^{-}}{ }^{15} \mathrm{~N}$ & $3.33 \pm 0.10$ & $8.98 \pm 0.09$ & $1.08 \pm 0.03$ & $9.42 \pm 0.08$ \\
\hline
\end{tabular}

\subsection{Soil exchange properties}

The amount of exchangeable base cations, exchangeable acidity and CEC of the soils are shown in Table 3. After the cultivation of tea plants, the amount of soil exchangeable base cations decreases, hence the soil exchangeable acidity increases, and the soil base cation saturation decreases substantially. After the cultivation of tea plants for $56 \mathrm{~d}$ the exchangeable acidity of yellow brown soil increased to $5.25 \mathrm{cmol} / \mathrm{kg}$, and the total base cations decreased to $5.60 \mathrm{cmol} / \mathrm{kg}$. Similarly, the base cation saturation decreased to $50.82 \%$. These results are consistent with the trends of the change of the corresponding soil $\mathrm{pH}$. In comparison for the data from different soils, the total base cations and base cation saturation of the soils generally increased with the increase of fertilization, while the soil exchangeable acidity changed in the opposite trend (Table 3). Soil acidification also changes soil CEC. Therefore, soil acidification decreases not only the content of soil base cations and base cation saturation of the soil, but also the soil CEC.

Table 3 Chemical properties of the soils with different treatments

\begin{tabular}{|c|c|c|c|c|c|c|c|c|c|}
\hline \multirow{2}{*}{ Soil } & \multirow{2}{*}{ Treatment } & \multicolumn{5}{|c|}{ Exchangeable base cations $/\left(\mathrm{cmol} \cdot \mathrm{kg}^{-1}\right)$} & \multirow{2}{*}{$\begin{array}{l}\text { Exchangeable acidity } \\
\qquad /\left(\mathrm{cmol} \cdot \mathrm{kg}^{-1}\right)\end{array}$} & \multirow{2}{*}{$\mathrm{CEC}$} & \multirow{2}{*}{$\begin{array}{l}\text { Base cation } \\
\text { saturation } / \%\end{array}$} \\
\hline & & $\mathrm{Ca}^{2+}$ & $\mathrm{Mg}^{2+}$ & $\mathrm{K}^{+}$ & $\mathrm{Na}^{+}$ & Total & & & \\
\hline \multirow{2}{*}{ Brown soil } & $\mathrm{NO}_{3}{ }^{-15} \mathrm{~N}$ & 7.80 & 4.67 & 0.25 & 0.52 & 13.24 & 0.62 & 13.36 & 99.10 \\
\hline & $\mathrm{NH}_{4^{-}}{ }^{15} \mathrm{~N}$ & 7.45 & 4.77 & 0.16 & 0.26 & 12.64 & 0.58 & 13.26 & 95.32 \\
\hline \multirow{2}{*}{ Red soil } & $\mathrm{NO}_{3}{ }^{-15} \mathrm{~N}$ & 5.95 & 2.82 & 0.19 & 0.27 & 9.23 & 3.05 & 10.61 & 86.99 \\
\hline & $\mathrm{NH}_{4^{-}}{ }^{15} \mathrm{~N}$ & 5.09 & 2.70 & 0.18 & 0.15 & 8.12 & 3.13 & 11.39 & 71.29 \\
\hline \multirow{2}{*}{ Yellow brown soil } & $\mathrm{NO}_{3}-{ }^{15} \mathrm{~N}$ & 4.38 & 1.66 & 0.18 & 0.17 & 6.39 & 5.14 & 9.98 & 64.03 \\
\hline & $\mathrm{NH}_{4-}{ }^{15} \mathrm{~N}$ & 3.79 & 1.29 & 0.21 & 0.31 & 5.60 & 5.25 & 11.02 & 50.82 \\
\hline \multirow{2}{*}{ Yellow soil } & $\mathrm{NO}_{3}-{ }^{15} \mathrm{~N}$ & 7.07 & 4.30 & 0.12 & 0.35 & 11.84 & 3.06 & 13.10 & 90.38 \\
\hline & $\mathrm{NH}_{4-}{ }^{15} \mathrm{~N}$ & 6.96 & 3.67 & 0.21 & 0.28 & 11.12 & 3.23 & 12.17 & 91.37 \\
\hline
\end{tabular}

\section{Conclusions}

This study showed that with the increase of cultivation time, the soil $\mathrm{pH}$ decreased obviously, and the growth of tea tree is the cause of soil acidification. For the two types of nitrogen fertilizer, soil applied with $\mathrm{NO}_{3}-{ }^{-15} \mathrm{~N}$ have slower $\mathrm{pH}$ drop than soil applied with $\mathrm{NH}_{4}{ }^{15} \mathrm{~N}$ in the four types of soil. Nitrogen cycle accompanied by $\mathrm{H}^{+}$uptake and release. Ammonification each release $1 \mathrm{~mol} \mathrm{NH}_{4}^{+}$, can absorb $1 \mathrm{~mol} \mathrm{H}^{+}$; nitrification oxide $1 \mathrm{~mol}$ of $\mathrm{NH}_{4}^{+}$can change into $1 \mathrm{~mol} \mathrm{NO}_{3}^{-}$, release $2 \mathrm{~mol} \mathrm{H}^{+}$into the environment. It can be concluded that ammonium nitrogen nitrification process released $\mathrm{H}^{+}$leading to the emergence of this phenomenon, so the ammonium nitrogen fertilizer applied exacerbate tea garden soil acidification. The absorption of nitrogen and nitrogen fertilizer utilization efficiency of tea tree showed that the growth of tea tree is closely related with the nitrogen fertilizer. The demand of nitrogen for tea tree is particularly large, and application of nitrogen fertilizer benefits tea tree growth and production. At the same time ammonium nitrogen uptake and utilization of tea tree were significantly higher than nitrate nitrogen, showed that tea tree is fond of ammonium nitrogen.

\section{Acknowledgements}

This project was financially supported by the National Natural Science Funds of China under the contract of No. 41201224, 31200035 .

\section{[References]}

[1] International Tea Committee. Annual Bulletin of Statistics, London, 2004.

[2] Song M, Liu Y. Effect of biogeochemical cycle in tea garden on the soil acidification. Journal of Tea Science, 1990; 10(2): 19-26. (in Chinese)

[3] Ding R X, Huang X A. Biogeochemical cycle of aluminum and fluorin in a tea garden soil system and its relationship to soil acidification. Acta Pedologica Sinica, 1991; 28(3): 229-236. (in Chinese)

[4] Ruan J Y, Gerendás J, Härdter R. Effect of nitrogen form and root-zone $\mathrm{pH}$ on growth and nitrogen uptake of tea (Camellia sinensis) plants. Annals of Botany, 2007; 99: 301-310.

[5] Baruah B K, Das B, Medhi C, Misra A K. Fertility status of soil in the tea garden belts of Golaghat District, Assam, India. Journal of Chemistry, 2013; 2013: 1-6. 
[6] Dutta J, Bhuyan B, Misra A K. A case study on soil acidity and metal contents in and around the tea gardens of Sonitpur District, Assam (India). Journal of Environmental Research and Development, 2009; 3(4): 1108-1113.

[7] Jiang J, Xu R K, Li J Y, Zhao A Z . Preliminary study on amelioration of an acid soil from a tea garden by plant materials. Soils, 2007; 39(2): 322-324.

[8] Gregory M, Martha M, Rhae D. Sorghum growth, root responses, and soil-solution aluminum and manganese on $\mathrm{pH}$-stratified sandy soil. Plant Nutrition and Soil Science, 2009; 172: 108-117.

[9] Ruan J Y, Ma L F, Shi Y Z. Aluminium in tea plantations; mobility in soils and plants, and the influence of nitrogen fertilizers. Environmental Geochemistry and Health, 2006; 28: 519-528.

[10] Guo J H, Liu X J, Zhang Y. Significant acidification in major Chinese croplands. Science, 2010; 327: 1008-1110.

[11] Liang Y R, Zhao Q Q, Lu J L, Liu Z S. Effect of pruned tea leaf and various nitrogen fertilizers on soil $\mathrm{pH}$ and activated aluminum content. Journal of Tea, 2000; 4: 205-208.

[12] Dong W Y, Nie L S, Wei A T, Shen Y B, Zhang Z Y. Effects of nitrogen forms on the absorption and distribution of nitrogen in Populus tomentosa seedlings using the technique of ${ }^{15} \mathrm{~N}$ tracing. Journal of Beijing Forestry University, 2009; 31(4): 97-101.

[13] Dong W Y, Nie L S, Wei A T, Li J Y, Shen Y B, Zhang Z Y. The absorption, utilization and distribution of nitrate ${ }^{15} \mathrm{~N}$ and ammonium ${ }^{15} \mathrm{~N}$ in Populus Tomentosa seedlings. Journal of Nuclear Agricultural Sciences, 2009; 23(3): 501-505.

[14] Aitken R L, Moody P W. The effect of valence and ionic strength on the measurement of $\mathrm{pH}$ buffer capacity. Australian Journal of Soil Research, 1994; 32: 975-984

[15] Pansu M, Gautheyrou J. Handbook of soil analysis-mineralogical, organic and inorganic methods. Springer-Verlag Berlin, Heidelberg, 2006.

[16] Zhao Z P, Yan S, Liu F, Ji PH, Wang X Y, Tong, Y A. Effects of chemical fertilizer combined with organic manure on Fuji apple quality, yield and soil fertility in apple orchard on the Loess Plateau of China. Plant Science, Int J Agric \& Biol Eng, 2014; 7(2): 45-55.

[17] Wang H, Wang N, Xu R K, Li X H. Soil acidification of Alfisols as influenced by tea plantation in eastern China. Pedosphere, 2010; 20(6): 799-806.

[18] Li J Y, Xu R, Xiao S C. Effect of low-molecular-weight organic anions on exchangeable aluminum capacity of variable charge soils. Colloid and Interface Science, 2005; 284(2): 393-399.
[19] Xu R K, Coventry D R. Soil pH changes associated with lupin and wheat plant materials incorporated in a red-brown earth soil. Plant and Soil, 2003; 250: 113-119.

[20] Yang Y J. China tea plant cultivation. Shanghai Science and Technology Press, Shanghai, 2005. (in Chinese)

[21] Abera G, Wolde-Meskel E, Bakken LR. Carbon and nitrogen mineralization dynamics in different soils of the tropics amended with legume residues and contrasting soil moisture contents. Biology and Fertility of Soils, 2012; 48(1): 51-66.

[22] Dessureault-Rompré J, Zebarth B J, Georgallas A, Burton D L, Grant C A, Drury C F. Temperature dependence of soil nitrogen mineralization rate: comparison of mathematical models, reference temperatures and origin of the soils. Geoderma, 2010; 157(3): 97-108.

[23] Ye C, Cheng X, Zhang Y, Wang Z X, Zhang Q F. Soil nitrogen dynamics following short-term revegetation in the water level fluctuation zone of the Three Gorges Reservoir, China. Ecological Engineering, 2012; 38(1): 37-44.

[24] Xiao K, Xu J, Tang C, Zhang JB, Brookes PC Differences in carbon and nitrogen mineralization in soils of differing initial $\mathrm{pH}$ induced by electrokinesis and receiving crop residue amendments. Soil Biology and Biochemistry, 2013; 67: 70-84.

[25] Yao H, Campbell C D, Qiao X. Soil pH controls nitrification and carbon substrate utilization more than urea or charcoal in some highly acidic soils. Biology and Fertility of Soils, 2011; 47(5): 515-522.

[26] Fu B, Qi Y B, Chang Q R. Impacts of revegetation management modes on soil properties and vegetation ecological restoration in degraded sandy grassland in farming-pastoral ecotone. Int J Agric \& Biol Eng, 2015; 8(1): 26-34.

[27] Tong D L, Xu R K, Gu T X. Effect of application of urea and ammonium sulfate on nitrification and acidification in rea soils in different in initial pH. Journal of Ecology and Rural Environment, 2012; 28(4): 404-409.

[28] Xue D, Huang X, Yao H, Huang C Y. Effect of lime application on microbial community in acidic tea orchard soils in comparison with those in wasteland and forest soils. Journal of Environmental Sciences, 2010; 22(8): 1253-1260.

[29] Wang F, Chen Y Z, You Z M, Wu Z D, Jiang F Y, Zhang W J, et al. Effects of different nitrogen application rates on nitrification and $\mathrm{pH}$ of two tea garden soil. Journal of Tea Science, 2015; 35(1): 82-90.

[30] Tong D L, Xu R K. Effects of urea $\left(\left(\mathrm{NH}_{4}\right)_{2} \mathrm{SO}_{4}\right)$ and $\mathrm{NH}_{4} \mathrm{HCO}_{3}$ on nitrification and acidification of a red soil. Plant Nutrition and Fertilizer Science, 2012; 18(4): 853-859. 